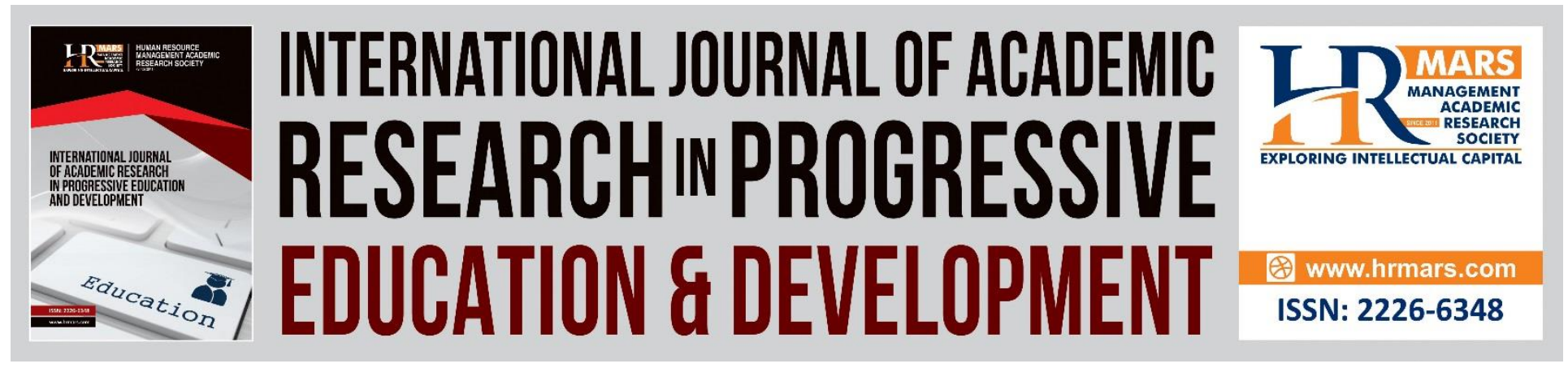

\title{
Students' Perception of Online Class During Covid-19 Pandemic: An Ordered PROBIT Model Estimation
}

Sourav Das, Md. Emran Hossain, Kulsum Akter

To Link this Article: http://dx.doi.org/10.6007/IJARPED/v10-i2/9685

DOI:10.6007/IJARPED/v10-i2/9685

Received: 05 February 2021, Revised: 28 February 2021, Accepted: 19 March 2021

Published Online: 22 April 2021

In-Text Citation: (Das et al., 2021)

To Cite this Article: Das, S., Hossain, M. E., \& Akter, K. (2021). Students' Perception of Online Class During Covid19 Pandemic: An Ordered PROBIT Model Estimation. International Journal of Academic Research in Progressive Education and Development, 10(2), 392-401.

Copyright: (c) 2021 The Author(s)

Published by Human Resource Management Academic Research Society (www.hrmars.com)

This article is published under the Creative Commons Attribution (CC BY 4.0) license. Anyone may reproduce, distribute, translate and create derivative works of this article (for both commercial and non-commercial purposes), subject to full attribution to the original publication and authors. The full terms of this license may be seen at: http://creativecommons.org/licences/by/4.0/legalcode

Vol. 10(2) 2021, Pg. 392 - 401

http://hrmars.com/index.php/pages/detail/IJARPED

JOURNAL HOMEPAGE

Full Terms \& Conditions of access and use can be found at http://hrmars.com/index.php/pages/detail/publication-ethics 


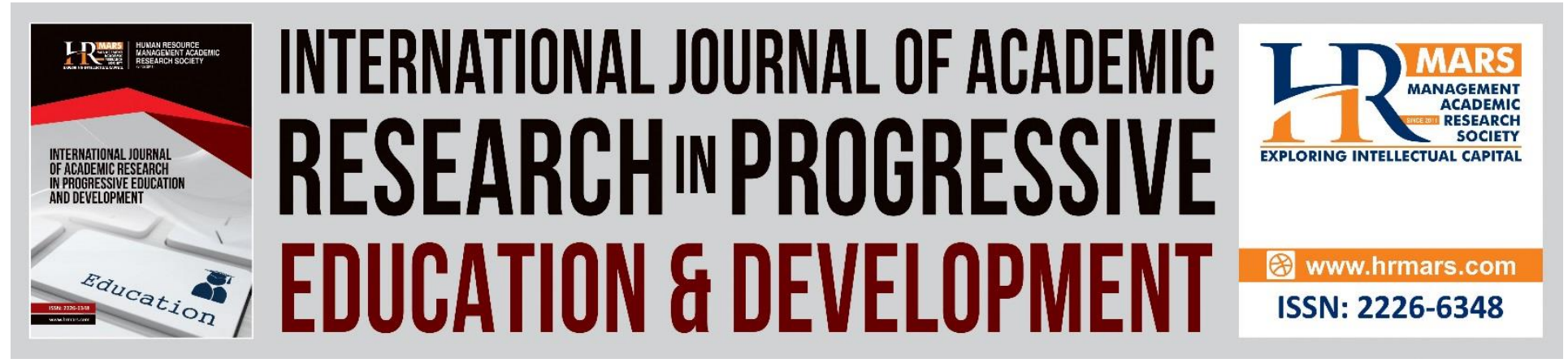

\title{
Students' Perception of Online Class During Covid- 19 Pandemic: An Ordered PROBIT Model Estimation
}

\author{
Sourav Das \\ University of Kassel Germany \\ Email: uk068041@student.uni-kassel.de \\ Md. Emran Hossain, Kulsum Akter \\ Bangladesh Agricultural University Bangladesh \\ Email: emran49011@bau.edu.bd, kulsumakter480@gmail.com
}

\begin{abstract}
In this study we have examined the students' perception of online class during COVID-19 pandemic based on a telephone survey among 200 public university students in Bangladesh. Our ordered probit model estimation shows that gender, living area, money spending for online classes, academic grade, internet problem, consideration of online class as a good alternative, considering whether teachers are skilled or not significantly affect the students' perception of online class. Students having lower facilities, for example internet problems, living in rural areas, unskilled teachers, lower spending (because of poor economic status) tend to choose a very bad perception of online class. Besides students with lower grades, students who don't consider online classes as a good alternative and female students tend to choose very bad perceptions of online class.
\end{abstract}

Keywords: COVID-19, Perception, Ordered Probit Model.

\section{Introduction}

The first case of COVID-19 appeared in Wuhan city, China in December, 2019 (Azlan et al., 2020; Xiao et al., 2020; Guan et al., 2020; Mizumoto et al., 2020), and rapidly spread not only throughout China but also across the world (Yashavantha and Jayabaskaran, 2020). However, the spreading dynamics of COVID-19 was unexpectedly very high (Huang et al., 2020; Zeng et al., 2020), and the number of cases increased in a very short time. Consequently, the World Health Organization (WHO) announced the COVID-19 as a pandemic on March 11, 2020 (Eroğlu, 2020).

The first case of COVID-19 in Bangladesh was confirmed on March 8, 2020 (Shammi et al., 2020; Anwar et al., 2020). The government declared a lockdown on March 26, 2020 throughout the country since the number of cases increased drastically (Shammi et al., 2020). Due to the 
COVID-19 pandemic and lockdown Bangladesh has experienced a significant effect on health, economy, education, tension, depression, loneliness and so on (Sherman et al., 2020; Narayanan et al., 2020; Singh and Singh, 2020). Besides due to closure of all the educational institutions, millions of students found themselves in an inimical position regarding the learning process. To tackle this situation, some of the educational institutes have introduced online learning platforms to keep the academic activities going on (Muthuprasad et al., 2021). Educational institutions and students across the world have preferred and appreciated online learning due to ease of use, learning flexibility, controllable environment and no better alternative (Khan et al., 2021). However, despite its advantages, the concern about the class preparation, designing and effectiveness of e-learning is still not apparently conducive, particularly for a developing country like Bangladesh (Alam, 2020).

The technical constraints like unavailability of smart devices or laptop and undisturbed internet pose a thoughtful challenge for many students in Bangladesh. Many students don't have the ability to sustainably access to the classes (because they reside in rural areas where internet and uninterrupted supply of electricity is still out of service). However, a little portion of students who live in modern towns can benefit from online classes because of steady bandwidth connection. On the other hand, teachers in Bangladesh are not well capable and skilled to conduct class through online, also they may not run the online class according to the specific plan. As a result, this may create a considerable challenge for online education in Bangladesh and hinder the learning process.

Some studies try to assess the online class perception of students during Covid-19 in different developed and emerging countries (Agarwal and Kaushik, 2020; Khan et al., 2020; Nambiar, 2020; Surani and Hamidah, 2020; Agung et al., 2020; Baber, 2020; Chick et al., 2020; Ferrel and Ryan, 2020; Torda et al., 2020; Rajab et al., 2020; Abbasi et al., 2020). However, most of the studies consider the COVID-19 impact on medical education apart from other curricula. Regarding the results, a kind of dissimilar perception has been found for developing and developed countries. Against such a backdrop, this study aims to examine the following research questions-

- What is the students' perception of online class during COVID-19 pandemic in Bangladesh?

- What factors are affecting this perception of online class during COVID-19 pandemic in Bangladesh?

The remaining parts of this paper focus on methodological approach (section 2), explaining data and variables (section 3), discussion about descriptive statistics as well as ordered probit model estimation (section 4) and finally summary and conclusion (section 5).

\section{Methodological Approach}

In this study our dependent variable follows the ordered nature. That's why we have selected ordered probit model for our analysis. The ordered probit model was developed by McKlvey and Zavoina (1975). It assumes the error terms $\varepsilon_{i}$ are standard normally distributed (in case of ordered logit model $\varepsilon_{i}$ is logistic distributed). In ordered probit model the latent continuous variable $\left(y_{i}{ }^{*}\right)$ follows the following formula-

$\mathrm{y}_{\mathrm{i}}^{*}=\mathrm{x}_{\mathrm{i}} \mathrm{b}+\varepsilon_{\mathrm{i}}, \varepsilon_{\mathrm{i}} \sim \mathrm{N}(0,1)$ (Jackman, 2000) ----(i) 
here, $x_{i}$ indicates vector of independent explanatory variables, and $\varepsilon_{i}$ is the standard normally distributed error term. In equation (i), it is not possible to observe the continuous latent variable $\left(\mathrm{y}_{\mathrm{i}}{ }^{*}\right)$. But it is possible to observe $\mathrm{y}_{\mathrm{i}}$ (with $\mathrm{k}=1, \ldots, \mathrm{K}$ categories and individual-specific thresholds $\lambda_{k}^{i}$, where $\left.\lambda_{k}^{i}<\lambda_{k+1}^{i}\right)$. So,

$\mathrm{y}_{\mathrm{i}}=\mathrm{k} \Leftrightarrow \lambda_{k}^{i} \leq \mathrm{y}_{\mathrm{i}}{ }^{*}<\lambda_{k+1}^{i}$ (Geishecker \& Riedl, 2010) ----(ii)

Using the threshold parameters $\lambda_{0}, \lambda_{1}, \ldots, \lambda_{\mathrm{k}}$ with $\lambda_{0}<\lambda_{1}<\cdots<\lambda_{\mathrm{k}}$ the latent variable $\left(\mathrm{y}_{\mathrm{i}}{ }^{*}\right)$ can be divided in $\mathrm{k}$ intervals where the higher values of the latent variable $\left(\mathrm{y}_{\mathrm{i}}{ }^{*}\right)$ lead to higher values of $y$.

The marginal effect of the probabilities follows the following formula-

$\frac{\partial \operatorname{Pr}\left[y_{i}=k\right]}{\partial x_{i}}=\left\{\mathrm{F}^{\prime}\left(\alpha_{\mathrm{j}-1}-\mathrm{x}^{\prime}{ }_{\mathrm{k}} \beta\right)-\mathrm{F}^{\prime}\left(\alpha_{\mathrm{j}}-\mathrm{x}^{\prime}{ }_{\mathrm{k}} \beta\right)\right\} \beta$ (Cameron \& Trivedi, 2005, p. 520)

\section{Data and Variables}

The data has been collected by a telephone survey among 200 public university students in Bangladesh. Because of COVID-19 restrictions in Bangladesh all the educational institutions (except the religious education centres) were closed. So, a telephone survey was the easiest way to reach the students than direct survey. We have taken the list of students from different social media groups (where most of the students are involved) and with the cooperation of class representatives of different universities. Then we have randomly selected 200 students for our study.

\section{Dependent Variables}

The dependent variable "evaluation of online class" is a categorical variable consisting of 5 categories. The respondents were asked about how they will evaluate online class comparing present class. The respondents answered this question under five categories: "Very bad", "Bad", "Satisfactory", "Good" and "Very good", where this study considers 1 for "Very bad" and similarly "Bad", "Satisfactory", "Good" , "Very good" take respectively 2, 3, 4 and 5. 
DEVELOPMENT

Vol. 10, No. 2, 2021, E-ISSN: 2226-6348 @ 2021 HRMARS

\begin{tabular}{l} 
Explanatory Variables \\
\begin{tabular}{|l|l|}
\hline Variable & Description \\
\hline Gender & $\begin{array}{l}\text { It is a dummy variable taking value } 1 \text { if the respondent is } \\
\text { male and } 0 \text { if respondent is female. }\end{array}$ \\
\hline Spend & $\begin{array}{l}\text { It is a dummy variable taking value } 1 \text { if the respondent } \\
\text { lives in an urban area and 0 if respondent lives in a rural } \\
\text { area. }\end{array}$ \\
\hline Alternative & $\begin{array}{l}\text { It is a continuous variable. It indicates the amount of } \\
\text { spending per month to participate in the online classes } \\
\text { (this spending basically includes buying internet } \\
\text { packages or amount of monthly private WiFi charge.) }\end{array}$ \\
\hline Teachers & $\begin{array}{l}\text { It is a dummy variable taking value } 1 \text { if the respondent } \\
\text { thinks that online class is a good alternative in this } \\
\text { COVID-19 pandemic and 0 otherwise. }\end{array}$ \\
\hline Int. problem & $\begin{array}{l}\text { It is a dummy variable taking value } 1 \text { if the respondent } \\
\text { thinks that most of their teachers are well skilled for } \\
\text { online class and } 0 \text { otherwise. }\end{array}$ \\
\hline Grade & $\begin{array}{l}\text { It is a dummy variable taking value } 1 \text { if the respondent } \\
\text { faces internet problems during the class and } 0 \\
\text { otherwise. }\end{array}$ \\
\hline It is a continuous variable. It indicates the average grade \\
of the respondent until the date when they were \\
surveyed.
\end{tabular} \\
\hline
\end{tabular}

\section{Results}

The descriptive statistics of all explanatory variables has been represented in Table 1 where we can see the frequencies of the dummy variables as well as the mean and standard deviation of the continuous variables. Table 2 represents the frequencies of dependent variables. It indicates that about 12.50 percent out of the 200 respondents state their perception of online class as "Very bad". "Bad", "Good" and "Very good" perceptions of online class are reported by respectively 20, 23 and 8.50 percent respondents. At the same time, most of our respondents (36 percent) report "Satisfactory" perception of online class.

Table 3 reports the results of ordered probit model for 200 respondents. According to the coefficient of "Gender" (the effect is statistically significant at $1 \%$ level of significance), male students have a strong significant positive effect on the choice of "Very good" and a strong significant negative effect on the choice of "Very bad". On the other hand, female students have a strong significantly negative effect on the choice of "Very good" and a strong significantly positive effect on the choice of "Very bad". Similarly, "Living", "Spend", "Alternative", "Grade" have a strong significant positive effect on the choice of "Very good" and a strong significant negative effect on the choice of "Very bad". Besides, "Teachers" has a strong significant positive effect and "Int. problem" has a strong significant negative effect on the choice of "Very good" at $5 \%$ level of significance. 
Table 4 reports the marginal effect. It provides the direction of the probabilities. For example, if "Spend" increases by 1 unit, the estimated average probability (across all respondents) of considering "Very bad" will be decreased by approximately 0.02 percentage point and the estimated average probability (across all respondents) of considering "Very Good" will be increased by approximately 0.01 percentage point. In case of "Teachers" (taking as an example of dummy variable), the estimated average probability (across all respondents) of considering "Very good" for the students who think most of the teachers are skilled for online class is 4.14 percentage point higher than the students who don't think that most of the teachers are skilled for online class. The marginal effect of the remaining variables can be interpreted in the same manner.

\section{Summary $\&$ Conclusion}

In this paper we have empirically analysed the evaluation of online class during COVID-19 pandemic. Based on a telephone survey among 200 public university students in Bangladesh we find that although a large share of the students are considering online class as "Satisfactory", but regarding different factors the perception is varying. Students who report lower spending for online classes (for poor economic status), have lower academic grade, live in rural area, are not satisfied with teacher's skill of online class, face internet problem, don't consider online class as a good alternative and also female students have a negative view toward online class (compared to the opposite factors, for example higher spending for online class, high academic grade and so on). The findings satisfy our research question. The findings also suggest that to make online classes more efficient we should take care of these perceptions of students. Taking this result into account we can provide scholarships or any other financial support for the students to make sure that they have sufficient internet packages. As around half of the respondents live in rural areas and $67 \%$ students face internet problems and both factors negatively affect their perception, the internet facilities as well as the disadvantages of rural students should be taken under consideration. Besides, teachers should be given proper training to make the online class enjoyable as well as special care should be given to the students having low academic grades. It is also clear that female students have a negative perception compared to male students. We can recommend further study to understand this effect. 
INTERNATIONAL JOURNAL OF ACADEMIC RESEARCH IN PROGRESSIVE EDUCATION AND DEVELOPMENT

Vol. 10, No. 2, 2021, E-ISSN: 2226-6348 @ 2021 HRMARS

\section{Tables}

Table 1: Descriptive statistics of explanatory variables:

For dummy variables:

\begin{tabular}{|l|l|l|}
\hline Variables & Frequency & Percentage \\
\hline Gender: & & \\
Male & 100 & $50 \%$ \\
Female & 100 & $50 \%$ \\
\hline Living: & 114 & $57 \%$ \\
Rural & 86 & $43 \%$ \\
Urban & & \\
\hline Alternative: & 91 & $45.5 \%$ \\
Good alternative & 109 & $54.5 \%$ \\
Not good alternative & & \\
\hline Teachers & 103 & $51.5 \%$ \\
Teachers are skilled: & 97 & $48.5 \%$ \\
Teacher are not skilled: & & $67 \%$ \\
\hline Int. problem & 134 & $33 \%$ \\
Have internet problem: & 66 & \\
Don't have internet & & \\
problem: & & \\
\hline
\end{tabular}

For continuous variables:

\begin{tabular}{|l|l|l|}
\hline Variables & Mean & Standard deviation \\
\hline Spend & 662.935 & 341.64 \\
\hline Grade & 3.3237 & 0.3123 \\
\hline
\end{tabular}

Table 2: Frequency table of the dependent variable

\begin{tabular}{|l|l|l|l|}
\hline $\begin{array}{l}\text { Evaluation of online } \\
\text { class }\end{array}$ & Frequency & Percentage & Cumulative \\
\hline Very bad & 25 & 12.50 & 12.50 \\
\hline Bad & 40 & 20.00 & 32.50 \\
\hline Satisfactory & 72 & 36.00 & 68.50 \\
\hline Good & 46 & 23.00 & 91.50 \\
\hline Very good & 17 & 8.50 & 100.00 \\
\hline
\end{tabular}


INTERNATIONAL JOURNAL OF ACADEMIC RESEARCH IN PROGRESSIVE EDUCATION AND DEVELOPMENT

Vol. 10, No. 2, 2021, E-ISSN: 2226-6348 @ 2021 HRMARS

Table 3: Ordered probit model estimation results:

\begin{tabular}{|c|c|c|c|}
\hline & Coefficients & $\mathrm{z}$ & $\mathrm{P}>|\mathrm{z}|$ \\
\hline Gender & 0.7876 & 4.51 & 0.000 \\
\hline Living & 0.5657 & 2.94 & 0.003 \\
\hline Spend & 0.0010 & 3.55 & 0.000 \\
\hline Alternative & 0.4820 & 2.57 & 0.010 \\
\hline Teachers & 0.3843 & 2.17 & 0.030 \\
\hline Int. problem & -0.4780 & -2.55 & 0.011 \\
\hline Grade & 0.8245 & 2.57 & 0.010 \\
\hline \multicolumn{2}{|c|}{ Log likelihood } & \multicolumn{2}{|c|}{-235.98303} \\
\hline \multicolumn{2}{|c|}{ Number of observations } & \multicolumn{2}{|c|}{200} \\
\hline \multicolumn{2}{|c|}{ Degrees of freedom } & \multicolumn{2}{|c|}{7} \\
\hline \multicolumn{2}{|l|}{ Prob > chi2 } & \multicolumn{2}{|c|}{0.0000} \\
\hline \multicolumn{2}{|l|}{ Pseudo R2 } & \multicolumn{2}{|c|}{0.2119} \\
\hline
\end{tabular}

Table 4: Marginal effects

\begin{tabular}{|l|c|c|c|c|c|}
\hline & Very bad & Bad & Satisfactory & Good & Very good \\
\hline Gender & $-0.1200^{* * *}$ & $-0.0811^{* * *}$ & 0.0080 & $0.1083^{* * *}$ & $0.0847^{* * *}$ \\
\hline Living & $-0.0862^{* * *}$ & $-0.0582^{* * *}$ & 0.0057 & $0.0778^{* * *}$ & $0.0609^{* * *}$ \\
\hline Spend & $-0.0002^{* * *}$ & $-0.0001^{* * *}$ & 0.0000 & $0.0001^{* * *}$ & $0.0001^{* * *}$ \\
\hline $\begin{array}{l}\text { Alternativ } \\
\text { e }\end{array}$ & $-0.0734^{* *}$ & $-0.0496^{* *}$ & 0.0049 & $0.0662^{* * *}$ & $0.0519^{* *}$ \\
\hline Teachers & $-0.0585^{* *}$ & $-0.0396^{* *}$ & 0.0039 & $0.0528^{* *}$ & $0.0414^{* *}$ \\
\hline $\begin{array}{l}\text { Int. } \\
\text { problem }\end{array}$ & $0.0728^{* *}$ & $0.0492^{* *}$ & -0.0049 & $-0.0657^{* *}$ & $-0.0514^{* *}$ \\
\hline Grade & $-0.1256^{* * *}$ & $-0.0849^{* *}$ & 0.0084 & $0.1133^{* *}$ & $0.0887^{* *}$ \\
\hline
\end{tabular}

In the figure above $* * *, * *$ and $*$ indicate statistical significance at the $1 \%, 5 \%$ and $10 \%$ level, respectively. 
INTERNATIONAL JOURNAL OF ACADEMIC RESEARCH IN PROGRESSIVE EDUCATION AND

DEVELOPMENT

Vol. 10, No. 2, 2021, E-ISSN: 2226-6348 @ 2021 HRMARS

\section{References}

Abbasi, S., Ayoob, T., Malik, A., \& Memon, S. I. (2020). Perceptions of students regarding Elearning during Covid-19 at a private medical college. Pakistan Journal of Medical Sciences, 36 (COVID19-S4), 57-61.

Agarwal, S., \& Kaushik, J. S. (2020). Student's perception of online learning during COVID pandemic. The Indian Journal of Pediatrics, 87, 554-554.

Agung, A. S. N., Surtikanti, M. W., \& Quinones, C. A. (2020). Students' Perception of Online Learning during COVID-19 Pandemic: A Case Study on the English Students of STKIP Pamane Talino. SOSHUM: Jurnal Sosial Dan Humaniora, 10(2), 225-235.

Alam, A. (2020). Challenges and Possibilities of Online Education during Covid-1. Preprints, 2020060013.

Anwar, S., Nasrullah, M., \& Hosen, M. J. (2020). COVID-19 and Bangladesh: Challenges and how to address them. Frontiers in public health, 8, 154-154.

Azlan, A. A., Hamzah, M. R., Sern, T. J., Ayub, S. H., \& Mohamad, E. (2020). Public knowledge, attitudes and practices towards COVID-19: A cross-sectional study in Malaysia. Plos one, 15(5), 1-15.

Baber, H. (2020). Determinants of students' perceived learning outcome and satisfaction in online learning during the pandemic of COVID-19. Journal of Education and E-Learning Research, 7(3), 285-292

Cameron, A., \& Trivedi, P. (2005). Microeconometrics: Methods and Applications. Cambridge University Press.

Chick, R. C., Clifton, G. T., Peace, K. M., Propper, B. W., Hale, D. F., Alseidi, A. A., \& Vreeland, T. J. (2020). Using technology to maintain the education of residents during the COVID-19 pandemic. Journal of surgical education, 77(4), 729-732.

Ferrel, M. N., \& Ryan, J. J. (2020). The impact of COVID-19 on medical education. Cureus, 12(3): e7492.

Eroğlu, H. (2020). Effects of Covid-19 outbreak on environment and renewable energy sector. Environment, Development and Sustainability, 23, 4782-4790.

Geishecker, I., \& Riedl, M. (2010). Ordered Response Models and Non-Random Personality Traits: Monte Carlo Simulations and a Practical Guide. Center for European Governance and Economic Development Research, Discussion Paper No. 116.

Guan, W. J., Ni, Z. Y., Hu, Y., Liang, W. H., Ou, C. Q., He, J. X., ... \& Zhong, N. S. (2020). Clinical characteristics of coronavirus disease 2019 in China. New England journal of medicine, 382(18), 1708-1720.

Huang, C., Wang, Y., Li, X., Ren, L., Zhao, J., Hu, Y., ... \& Cao, B. (2020). Clinical features of patients infected with 2019 novel coronavirus in Wuhan, China. The lancet, 395(10223), 497-506.

Jackman, S. (2000). Estimation and Inference via Bayesian Simulation: An Introduction to Markov Chain Monte Carlo. American Journal of Political Science, 44(2), 375-404.

Khan, M. A., Nabi, M. K., Khojah, M., \& Tahir, M. (2021). Students' Perception towards E-Learning during COVID-19 Pandemic in India: An Empirical Study. Sustainability, 13(1), 57.

McElvey, R., \& Zavoina, W. (1975). A Statistical Model for the Analysis of Ordered Level Dependent Variables. Journal of Mathematical Sociology, 4(1), 103-120. 
INTERNATIONAL JOURNAL OF ACADEMIC RESEARCH IN PROGRESSIVE EDUCATION AND

DEVELOPMENT

Vol. 10, No. 2, 2021, E-ISSN: 2226-6348 @ 2021 HRMARS

Mizumoto, K., Kagaya, K., \& Chowell, G. (2020). Early epidemiological assessment of the transmission potential and virulence of coronavirus disease 2019 (COVID-19) in Wuhan City, China, BMC medicine, 18(1), Article 217.

Muthuprasad, T., Aiswarya, S., Aditya, K. S., \& Jha, G. K. (2021). Students' perception and preference for online education in India during COVID-19 pandemic. Social Sciences \& Humanities Open, 3(1), 100101.

Nambiar, D. (2020). The impact of online learning during COVID-19: students' and teachers' perspective. The International Journal of Indian Psychology, 8(2), 783-793.

Narayanan, L., Pandit, M., Basu, S., Karmakar, A., Bidhan, V., Kumar, H., Brar, K. (2020). Impact of Lockdown due to COVID-19 Outbreak: Lifestyle Changes and Public Health Concerns in India. Preprints, 2020060129.

Rajab, M. H., Gazal, A. M., \& Alkattan, K. (2020). Challenges to online medical education during the COVID-19 pandemic. Cureus, 12(7):e8966.

Shammi, M., Bodrud-Doza, M., Islam, A. R. M. T., \& Rahman, M. M. (2020). Strategic assessment of COVID-19 pandemic in Bangladesh: comparative lockdown scenario analysis, public perception, and management for sustainability. Environment, Development and Sustainability, 23, 6148-6191.

Sherman, S. M., Smith, L. E., Sim, J., Amlôt, R., Cutts, M., Dasch, H., ... \& Sevdalis, N. (2020). COVID19 vaccination intention in the UK: results from the COVID-19 vaccination acceptability study (CoVAccS), a nationally representative cross-sectional survey. Human vaccines \& immunotherapeutics, 17(6), 1612-1621.

Singh, J., and Singh, J., (2020). COVID-19 and Its Impact on Society. Electronic Research Journal of Social Sciences and Humanities, 2(1), 168-172.

Surani, D., \& Hamidah, H. (2020). Students Perceptions in Online Class Learning During the Covid19 Pandemic. International Journal on Advanced Science, Education, and Religion, 3(3), 83-95.

Torda, A. J., Velan, G., \& Perkovic, V. (2020). The impact of the COVID-19 pandemic on medical education. Med J, 213(4), 188-188.

Xiao, H., Zhang, Y., Kong, D., Li, S., \& Yang, N. (2020). The effects of social support on sleep quality of medical staff treating patients with coronavirus disease 2019 (COVID-19) in January and February 2020 in China. Medical science monitor: international medical journal of experimental and clinical research, 5(26):e923549.

Rao, Y. H. C., \& Jayabaskaran, C. (2020). The emergence of a novel coronavirus (SARS-CoV-2) disease and their neuroinvasive propensity may affect in COVID-19 patients. Journal of medical virology, 92(7), 786-790.

Zeng, J., Huang, J., \& Pan, L. (2020). How to balance acute myocardial infarction and COVID-19: the protocols from Sichuan Provincial People's Hospital. Intensive care medicine, 46(6), 1111-1113. 